The Third Pole: Journal of Geography

Vol. 18 - 19: 71-84, 2019

DOI: https://doi.org/10.3126/ttp.v18i0.28008

Department of Geography Education,

Central Department of Education, T.U., Kathmandu, Nepal

\title{
LANDSLIDE HAZARD MAPPING: GIS BASED SUSCEPTIBILITY ASSESSMENT OF LEOUTIKHOLA WATERSHED, DHANKUTA, NEPAL
}

\author{
Tika Ram Linkha ${ }^{1}$ \\ Dil Kumar Rai ${ }^{2}$ \\ Furbe Lama ${ }^{3}$
}

\begin{abstract}
This article examines the landslide hazard mapping in Leoutikhola watershed of Dhankuta district, eastern hills of Nepal. The hills are regarded as one of the most vulnerable areas in the world. The area is prone to different types of natural hazards such as landslide, debris flow, gully erosion, mass wasting, and flooding. Various studies pointed out biophysical and socioeconomic factors are more responsible to landslide hazards in the hill-slope environment. This paper argues that the rainfall intensity, unscientific methods of cultivation and lack of environment friendly developmental activities in steep slope are some of the major driving factors to landslide in the Leoutikhola watershed area. Leoutikhola watershed area has been suffering from different types of natural hazards such as landslide, debris flow, gully erosion, mass wasting and flooding. Field verification and satellite imageries are the major sources for the information to analyze. Due to its fragile and very weak geological condition, geomorphic hazard is considered more common than other types of hazards which lose massive lives and property in the study area. The field observation and local people perception indicate a large amount of budget required to mitigate natural hazards in this area especially for landslide. In this context, this paper attempts to portray the landslide hazard zonation and susceptibility mapping correlated with various factors. For this purpose, bivariate statistical index and Geographic Information System (GIS) and Remote Sensing (RS) tools are used to calculate weighted values. The overall parameters indicate that in the series (-4.2 to
\end{abstract}

1 Linkha is a Lecturer, Department of Geography, Dhankuta Multiple Campus, Dhankuta, Tribhuvan University, Nepal.Email: tika.linkha@gmail.com.

2 Rai is a GIS Specialist, ASHA Project, Government of Nepal/IFAD.

3 Lama is a District Climate Change Specialist, ASHA project, Government of Nepal/IFAD). 
4.58) of five different hazard zones like very low, low, moderate, high and very high. The paper concludes that hazard determination calculated values indicate to 4.2 to -2.09 , -2.09 to $-1.0,-1.0$ to- $0.05,-0.05$ to 1.24 and 1.24 to 4.58 respectively in the range of quartile series.

Keywords: GIS, landslide, natural hazards, statistics, susceptible, watershed

\section{Introduction}

The term landslide includes the entire activities of debris flow, gully erosion, mass wasting and flooding. All types of mass movement of rock wastes including soils and ice are collectively called landslide. However, the term landslide consists of wide variety of processes that result in the downward and outward movement of slopes forming materials including rock, soil, artificial fill or a combination of these (Singh, 2012). Landslide is a form of mass movement where a displaced material retain its form as it moves. They become hazardous when they interfere with human activity. Huge loss of human life and property and a great amount of money spent on relief and recovery has been experiences in recent years due to increased landslide disaster in many parts of the world (Ghimire, 2011). The waste materials moving through different processes, such as falling, toppling, sliding, spreading or flowing. After the downward moving materials becoming more hazardous to lose immense lives, property and human activity. After the hazards occur, it requires a huge amount of money, human resources and time to recover it.

In Nepal, various studies have concluded that natural hazard is more common than other hazards. These studies highlighted that more than 80 percent of the total mountain environment is suffering from natural hazards. It is mainly due to steep slope, weak topography, fragile rock structure and high intensity of precipitation have made highly susceptible environment to landslide failure events (Upreti \& Dhital, 1996; Ayala, 2002; Pradhan, 2007; Dhakal et. al, 2000; Ghimire, 2011; Khanal et.al, 2013). However, physical and human induced factors are also equally significant to occur natural disasters in Nepal. According to Ayala (2002), natural disaster is increasing due to the high intense effect of natural hazards. There were a lot of studies have been made related to landslide hazard mapping (Laban, 1979; Ives \& Messerli, 1981; Kienholz et al, 1983; Heuberger, 1984; Dhital et.al, 1993; Gerrard \& Gardner, 2000) in different countries including Nepal. Their findings indicate that geomorphic processes e.g. landslide, debris flow and mass wasting of local relief features are more responsible for the growth and development of landslide hazards. These studies suggest to mitigate the in-situ landslide hazards events and possible methods and techniques regarding the landslide hazards (Dahal et al, 2008; 
Ghimire, 2011; Devkota et al, 2012; Pradhan \& Dawadi, 2013). They have employing bivariate method, GIS and Remote Sensing techniques for adapted landslide hazard mapping with correlating different dependent and independent variables.

The Central Bureau of Statics (CBS) has compiled four decadal of risks and vulnerability data since 1971-2011. The figure indicates that about 4976 individuals lose their lives, 1589 persons were injured, 33960 houses were damaged, 18491 destroyed and 574020 people's losses their properties in Nepal (CBS, 2013). These hazardous conditions are associated with the topographic features of the hilly terrains such as steep slope with narrow and rugged terrain. Other factors such as high relief, river bank cutting, weak geological conditions, intense precipitation, etc. are equally important to different types of landslide, mass movements and debris flow (Pradhan 2007, Khanal et.al, 2013). In addition, landslide dam outburst flood (LDOFs) is also affecting the lives and livelihoods of downstream communities.

Leoutikhola watershed has also suffered from landslide, debris flow, erosion and mass wasting hazards over centuries. However, nobody has yet made a comprehensive study to find out driving factors regarding landslide hazard in this area. In this context, this paper attempts to analyze unravelled questions that are the causal factors relating to landslide hazards and how we mitigate these problems with the application of GIS and Remote sensing techniques and statistical tools.

\section{Materials and Methods}

\section{Study area and Data Sources}

Study area. The Leoutikhola watershed area lies in the southern slope of the midhills of Nepal. This watershed is extent from $87^{\circ} 17^{\prime} 22^{\prime \prime}$ to $87^{\circ} 23^{\prime} 41^{\prime \prime}$ east longitude and $26^{\circ} 50^{\prime} 50^{\prime \prime}$ to $26^{\circ} 55^{\prime} 46^{\prime \prime}$ north latitude. The area of this watershed is 49.26 square kilometer whereas the elevation ranges from 249 to 2050 meter from sea level. The area is bordered by Main Boundary Thrust (MBT) with Chure formation in the south. The watershed originates from the southern slopes of the Dandabazar and Namje area and flowing towards the east-western direction to join Tamor River at Mulghat. Administratively, the watershed lies in the Sangurigadi Rural Municipality of Dhankuta district of province 1, eastern hills of Nepal (Fig. 1). The study area experiences warm temperate climate where summer is warm and moist as well as winter is cold and dry. The area received precipitation at varying rates during the monsoon season recorded 256 $\mathrm{mm}$ in July and $6 \mathrm{~mm}$ in December. The month of June obtains maximum temperature $\left(29.5^{\circ} \mathrm{C}\right.$.) and lowest in January $\left(8.1^{\circ} \mathrm{C}\right.$.) in 2011 . The climate variation in terms of precipitation between wet and hot season is $255 \mathrm{~mm}$ and the average temperature 
fluctuate during the year by $11.8^{0}$ centigrade. The highest precipitation recorded is 256 $\mathrm{mm}$ in July whereas lowest precipitation is $6 \mathrm{~mm}$ in December.

The total population of this area is 18322 , which comprises of 8346 males and 9976 females in 4232 households (CBS, 2011). Limbu is a dominant ethnic group of this area and followed by Rai in the second, and least by Chhetri and Brahmin. More than 80 percent of the total populations are dependent on subsistence agriculture occupation along with animal husbandry, forest-based activities. Some of the households are also involved in service, foreign employment, daily wage labor and casual works to earn their livelihood.

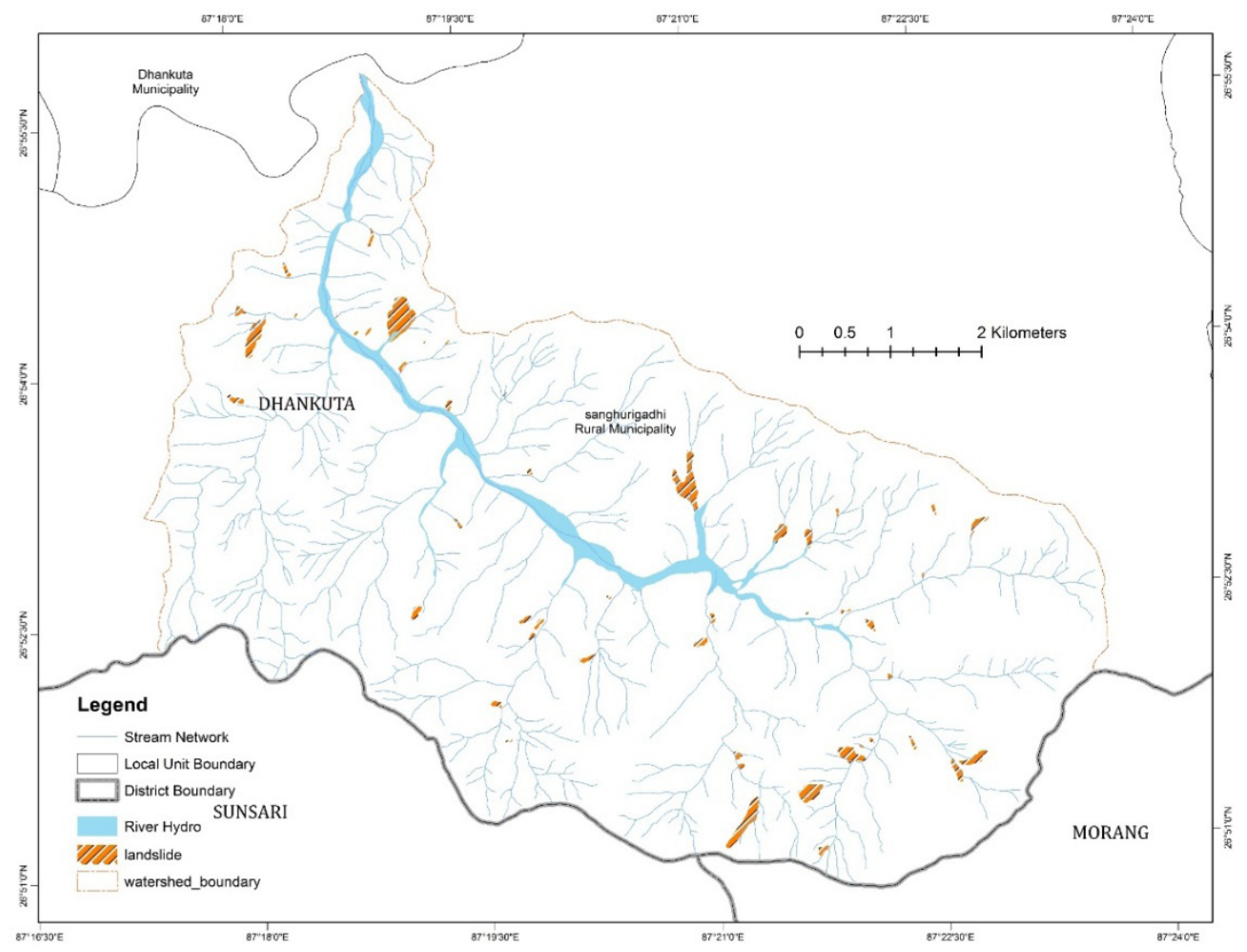

Figure 1: The location of the study area

Data sources. This paper is based on both primary and secondary data sources. Primary data were collected from various methods, such as field observation, focus group discussion, personal interviews, key informant interviews and field verification. Secondary data were collected from official records of DCC Dhankuta, Rural Municipality Office, Meteorological Station and District Statistical Office Dhankuta. 
GIS and remote sensing data were retrieved from Google Images and topographic maps on the scale of $(1: 25,000)$ obtained from Survey Department, Government of Nepal. The land use and land cover data extracted from the Landsat mission satellite with 30meter spatial resolution from the https://earthexplorer.usgs.gov.

Both mathematical and GIS/RS techniques were used for landslide hazard mapping in this article. For this process, different dependent and independent variables were prepared to test their statistical significance of landslide hazard events. In addition, average precipitation data of thirty years (1970-2000) were also calculated for spatially interpolated $(1 \mathrm{sq} . \mathrm{km})$ and it was extracted from global climate data through http/ worldclim.org. The soil texture data, land use and land cover map are prepared from these data. Spatial distribution of pond, lake and swamp database are also created by direct visual image interpretation of Google earth pro image superimposing different time period intervals of the study area and geology and lithology formation of the study area analyzed from http://rds.icimod.org.

\section{Table 1: Thematic data and their sources}

\begin{tabular}{l|l}
\hline Data description & Data sources \\
\hline $\begin{array}{l}\text { 1. Administrative unit \& topo thematic } \\
\text { layers }\end{array}$ & Survey Department, Government of Nepal \\
$\begin{array}{l}\text { 2. Current land use \& land cover } \\
\text { 3. Average precipitation }\end{array}$ & $\begin{array}{l}\text { Landsat with } 30 \mathrm{~m} \text { spatial resolution } \\
\text { Global climate data } 30 \text { years }(1970-2000)\end{array}$ \\
\hline
\end{tabular}

Source: Survey department, earth explorer, worldclim.org and cbs.gov.np

Application of bivariate statistical methods. The bivariate statistical index was applied to calculate landslide hazard mapping. This is the simple quantitative method and introduced by Van Western in 1984. This statistics is computed from the two variables to determine the reciprocal relationship among the variables. For this purpose, a weighted value for each parameter are assigned to calculate in-situ factors and natural logarithm given to calculate landslide density in the map (Western, 1997; Ghimire, 2011; Pradhan and Dawadi, 2013). The following formula can be used to compute the bivariate statistical index:

$$
\mathrm{W}_{1}=\ln \left(\frac{\text { Densclass }}{\text { Densemap }}\right)=\ln \frac{\operatorname{Npix}(\text { si }) / \operatorname{Npix}\left(N_{1}\right)}{\sum_{i=1}^{n=1} \operatorname{Npix}(s i) / \operatorname{Npix}\left(N_{1}\right)}
$$


Where,

$\mathrm{W}_{\mathrm{i}}=$ the weight given to a certain parameter class (e.g. land use $\&$ land cover, or a slope class)

Densclas $=$ the landslide density within the parameter class

Densmap $=$ the landslide density within the entire map

Npix $\left(\mathrm{S}_{\mathrm{i}}\right)=$ number of pixels, which contain landslides, in a certain parameter class

Npix $(\mathrm{Ni})=$ total number of pixels in a certain parameter class

The weighted value in the forms of natural logarithm is assigned to deterministic parameters under the GIS environment and the parameters assigned with weight overlay and finally, landslide hazard map or zone mapped and classified into different interval referenced to mathematical quartile numerical ranges.

\section{Results and Discussions}

Inventory \& mapping of landslide hazard distribution. This paper reveals the analysis of landslide hazard distribution on the basis of topographic map (scale: 1:25000). It can be classified in various ways: the prior level, current and fresh landslides. For this purpose, image visualization and interpretation from Google pro image with 5 meter spatial resolution of different periods were verified in the field.

Driving factors of landslides. Landslides are the product of a complex interplay of various triggering and conditioning in situ factors. Various methods, models, tools and techniques developed in geomorphology, geology and engineering knowledge should be necessary to appropriate understanding landslide. Although, this paper identified six different driving factors regarding the occurrences of landslides, such as slope, rainfall, land use and land cover, drainage density, relative relief and aspects. Both field observation and previous experiences on realization of geomorphic hazards were considered to prepare hazard mapping. This paper concludes that slope failure, debris flows and other factors are more influential to determine hazard mapping in the study area. Table 2 identifies the susceptibility weight for the analyzing landslide hazard driven factors. 
Tika Ram Linkha, Dil Kumar Rai \& Furbe Lama / Landslide Hazard Mapping: GIS ...

|| $77 \|$

Table 2: Determinant weights of in-situ factors for susceptibility of landslide hazard

\begin{tabular}{|c|c|c|c|c|c|c|c|}
\hline $\mathrm{SN}$ & Factor & Class & Landslide & $\begin{array}{l}\text { Landslide } \\
\text { Density }\end{array}$ & $\begin{array}{c}\text { Whole } \\
\text { landslide } \\
\text { density }\end{array}$ & $\begin{array}{l}\text { Weight } \\
\text { Class }\end{array}$ & Ln_Ratio \\
\hline \multirow{5}{*}{1.} & \multirow{5}{*}{$\frac{\tilde{2}}{\pi}$} & $<15^{0}$ & 25 & 0.00118 & 0.0034 & 0.35 & -1.05 \\
\hline & & $15^{0}-25^{0}$ & 88 & 0.00220 & 0.0034 & 0.65 & -0.42 \\
\hline & & $25^{0}-35^{0}$ & 214 & 0.00294 & 0.0034 & 0.88 & -0.13 \\
\hline & & $35^{0}-45^{0}$ & 250 & 0.00380 & 0.0034 & 1.13 & 0.12 \\
\hline & & $>45^{\circ}$ & 166 & 0.00774 & 0.0034 & 2.31 & 0.84 \\
\hline \multirow{5}{*}{2.} & \multirow{5}{*}{ 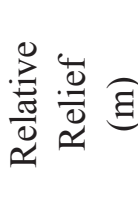 } & $<379$ & 3 & 0.00012 & 0.0034 & 0.036 & -3.335 \\
\hline & & $379-465$ & 143 & 0.00247 & 0.0034 & 0.737 & -0.306 \\
\hline & & $465-558$ & 398 & 0.00574 & 0.0034 & 1.712 & 0.538 \\
\hline & & $558-674$ & 147 & 0.00328 & 0.0034 & 0.980 & -0.020 \\
\hline & & $<674-843$ & 52 & 0.00212 & 0.0034 & 0.632 & -0.459 \\
\hline \multirow{5}{*}{3.} & \multirow{5}{*}{ 惡 } & $1284-1347$ & 253 & 0.00311 & 0.0034 & 0.929 & -0.074 \\
\hline & & $1347-1402$ & 215 & 0.00360 & 0.0034 & 1.075 & 0.072 \\
\hline & & $1402-1463$ & 33 & 0.00108 & 0.0034 & 0.324 & -1.127 \\
\hline & & $1463-1530$ & 216 & 0.00677 & 0.0034 & 2.018 & 0.702 \\
\hline & & $1530-1632$ & 26 & 0.00141 & 0.0034 & 0.420 & -0.867 \\
\hline \multirow{7}{*}{4.} & \multirow{7}{*}{ 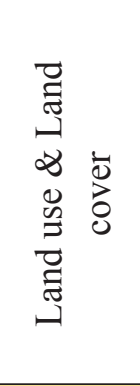 } & $\begin{array}{l}\text { Agriculture } \\
\text { land }\end{array}$ & 143 & 0.00159 & 0.0034 & 0.47 & -0.746 \\
\hline & & Barren land & 0 & 0 & 0.0034 & 0.00 & 0.000 \\
\hline & & Bush & 86 & 0.00459 & 0.0034 & 1.37 & 0.314 \\
\hline & & $\begin{array}{l}\text { Cutting \& } \\
\text { Cliff }\end{array}$ & 148 & 0.05824 & 0.0034 & 17.35 & 2.854 \\
\hline & & Forest land & 309 & 0.00300 & 0.0034 & 0.90 & -0.109 \\
\hline & & Grass & 45 & 0.02341 & 0.0034 & 6.98 & 1.942 \\
\hline & & Sand & 12 & 0.00217 & 0.0034 & 0.65 & -0.433 \\
\hline \multirow{6}{*}{5.} & \multirow{6}{*}{ 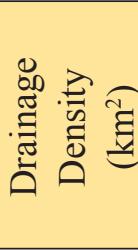 } & $0-0.69$ & 46 & 0.00122 & 0.0034 & 0.364 & -1.012 \\
\hline & & $0.69-1.33$ & 212 & 0.00320 & 0.0034 & 0.956 & -0.045 \\
\hline & & $1.33-1.97$ & 355 & 0.00562 & 0.0034 & 1.675 & 0.516 \\
\hline & & $1.97-2.78$ & 104 & 0.00304 & 0.0034 & 0.907 & -0.097 \\
\hline & & $2.78-4.12$ & 16 & 0.00110 & 0.0034 & 0.331 & -1.107 \\
\hline & & $4.12-6.07$ & 10 & 0.00169 & 0.0034 & 0.506 & -0.681 \\
\hline \multirow{4}{*}{6.} & \multirow{4}{*}{ 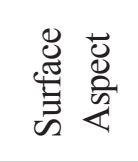 } & East & 194 & 0.00261 & 0.0034 & 0.778 & -0.251 \\
\hline & & South & 169 & 0.00379 & 0.0034 & 1.132 & 0.124 \\
\hline & & West & 246 & 0.00528 & 0.0034 & 1.575 & 0.455 \\
\hline & & North & 134 & 0.00239 & 0.0034 & 0.712 & -0.339 \\
\hline \multirow{5}{*}{7.} & \multirow{5}{*}{ 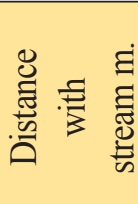 } & $<100$ & 2383 & 0.01675 & 0.0034 & 1.413 & 0.346 \\
\hline & & $100-200$ & 218 & 0.003815 & 0.0034 & 0.321 & -1.133 \\
\hline & & $200-300$ & 22 & 0.001399 & 0.0034 & 0.118 & -2.136 \\
\hline & & $300-400$ & 0 & 0 & 0.0034 & 0 & 0.00001 \\
\hline & & $400<$ & 0 & 0 & 0.0034 & 0 & 0.00001 \\
\hline
\end{tabular}

Source: In-situ factors \& observed landslide areas 
This paper calculates the slope gradient of the study area and it defined as an inclined unit on the surface of the earth. For this purpose, three measures can be used to calculate geometry of slope e.g. gradient, length \& width. The slope gradient is determined by the combination factors such as natures of materials, moisture conditions and controlling capacity of materials in the hill slope. However, steep slope is more prevalent to determine geomorphic processes and frequencies of landslides. The result reveals that the landslide occurrences and its distribution conditioned is largely determined by the slope gradient of the study area. The slope gradient ranges from 25 to 45 degrees in spatial coverage has occurred higher susceptibility of landslide hazards as compared to the low range of slope gradients.

This paper has also calculated the relative relief of the study area. It refers to the actual nonconformity of local relief height i.e. difference between maximum height and minimum height in per grid. The calculation of relative relief is one of the techniques, which effectively presents the relief characteristics of the study are without referencing sea level (Singh, 1992; Goudie, 1992). The result indicates that there is remarkable variation occurred on the local relief height within the very short distance in this watershed area. The calculated threshold value ranging from 379 to 674 meter of local height indicates to the higher rate of landslide hazard events. All these figures and facts reveals that the relative relief is one of the most important controlling factors for landslide hazard in the watershed area (Fig. 2).
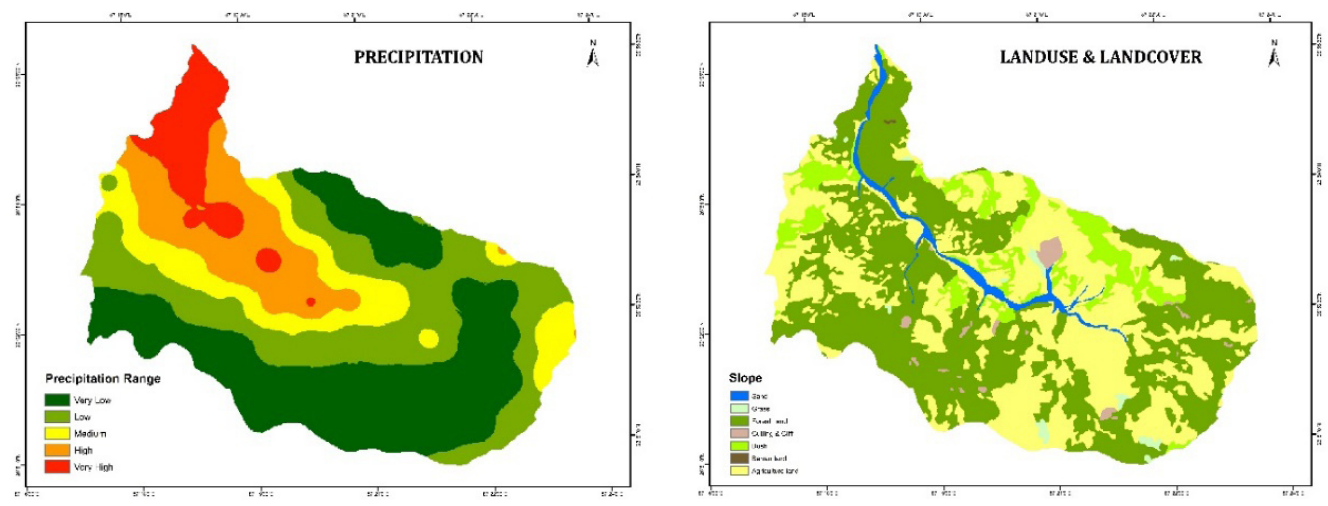

Figure 2: Maps of precipitation \&land use land cover factors

This paper also analyzed the relationship between rainfall and landslide in the watershed area. For this purpose, three decades (1970 -2000) average precipitation data are analyzed to calculate prepare landslide hazard mapping (Fig 3). The result indicates that the average rainfall ranges from 1284 to $1402 \mathrm{~mm}$ came to positive impact to the spatial interpolation of landslide hazard. The average rainfall data has a largest spatial coverage for the landslide distribution in the watershed area as compared to the similar studies in the middle hills of Nepal (Gardener \& Gerard, 2003; Devkota et. al, 2013). 

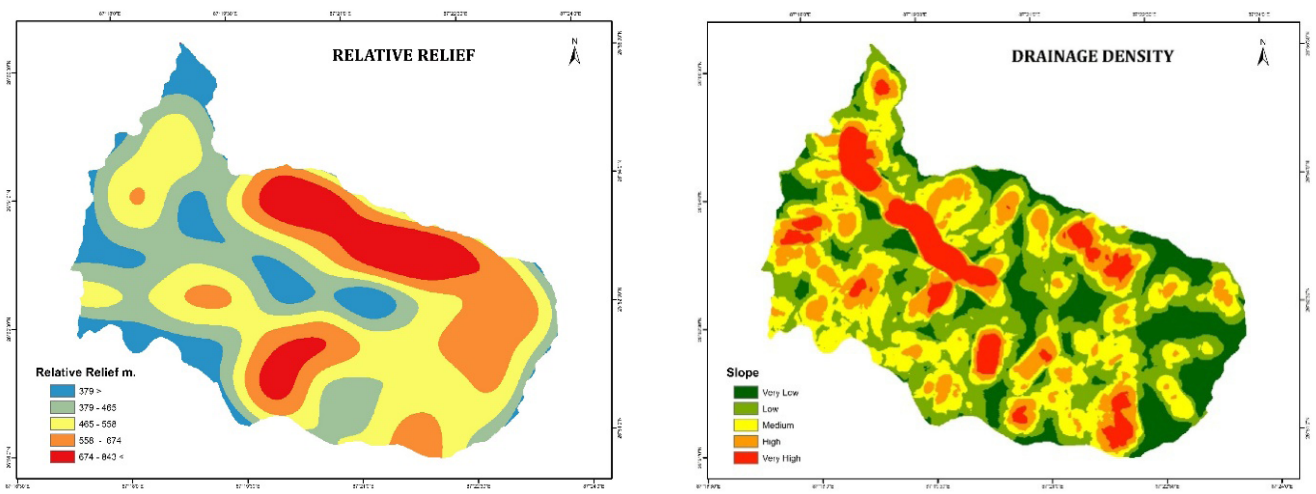

Figure 3: Maps of relative relief $\&$ drainage density factors

The forest coverage is another measure to reveal the occurrence of landslide in the watershed area. For this analysis slope, aspect and moistures condition and human induced factors such as population pressure were taken as indicators. One of the key informant reported that the policy and plans of local government for the extension of agricultural link roads, services and various developmental activities (rural-road) without environmental impact assessment has also accelerated to the landslide hazard due to very weak topography and fragile soil conditions. The drainage density has determined the runoff, infiltration and discharge of surface runoff (Figure 4). The drainage density denotes stream length per unit in the region (Horton, 1932), it indicates that high density of drainage network high run off and low infiltration functioning of dissection of landscape (Selby, 1993). In the watershed, the principle accords here show that most of the observed landslide areas distributed in the high dense of drainage networks consists to 0.69 to $2.78 \mathrm{sq}$. $\mathrm{km}$ belonging to narrow stream channel due to the construction of first order river basin-based valley top landscape are broad and wide ranging.
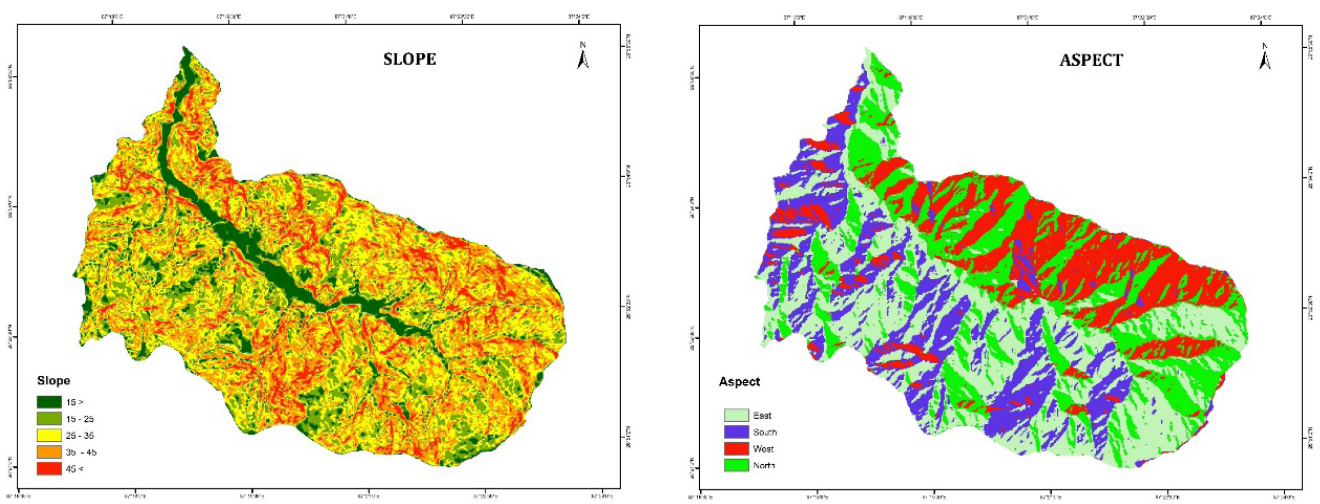

Figure 4: Maps of slope \& slope aspect factors 
Hence, difference in situ-factors have examined their role for landslide hazard mapping in the watershed level. The observed distribution of landslide areas on slope gradient of landscape topography reflects the majority of landslide scars found in slope gradients consists of above $25^{\circ}$ of the related landscapes or watershed. The relative relief ranges with 379 to 674 meter have predominately encountered with landslide hazard based on the distribution of landslide. The land use land cover features, agriculture land, forest land and bush area have well contribution to landslide hazard in the landscape. An average outline of precipitation has another factor for landslide hazard. The result reveals that the different aspects of landscape have a variation in its responses and reactions to hills slope processes and it depends on rock materials associated with cool and hot moisture. The west aspect has a significant role for landslide occurrences and followed by east and north directions. For instance, largest landslide patches found in the west south aspect of the watershed near the Budimorang village. The distribution of landslide hazard areas found near the mainstream of hydro stream. In this watershed, most of landslide areas have occurred close to mainstream of hydro stream because most of the observed landslides are distributed within 100 meters from major hydro stream. It indicates that the drainage morphology is the most dominant factors for hill slope materials and processes. It is estimated that about $80 \%$ of landslide distributions are observed at the near distance of main stream of hydro.

Susceptible hazard mapping. The susceptibility of landslide hazard mapping is one of the most important objectives of this paper. For this purpose, seven coherent driven factors were correlated to different hazard mappings in the watershed area. The result indicates that the analysis process and outputs were related to landslide incidences. For example, 75 percent landslide patches were randomly selected for the generation of landslide hazards and 25 percent patches were used to validate it. This paper uses bivariate statistical index for predicting landslide hazard.
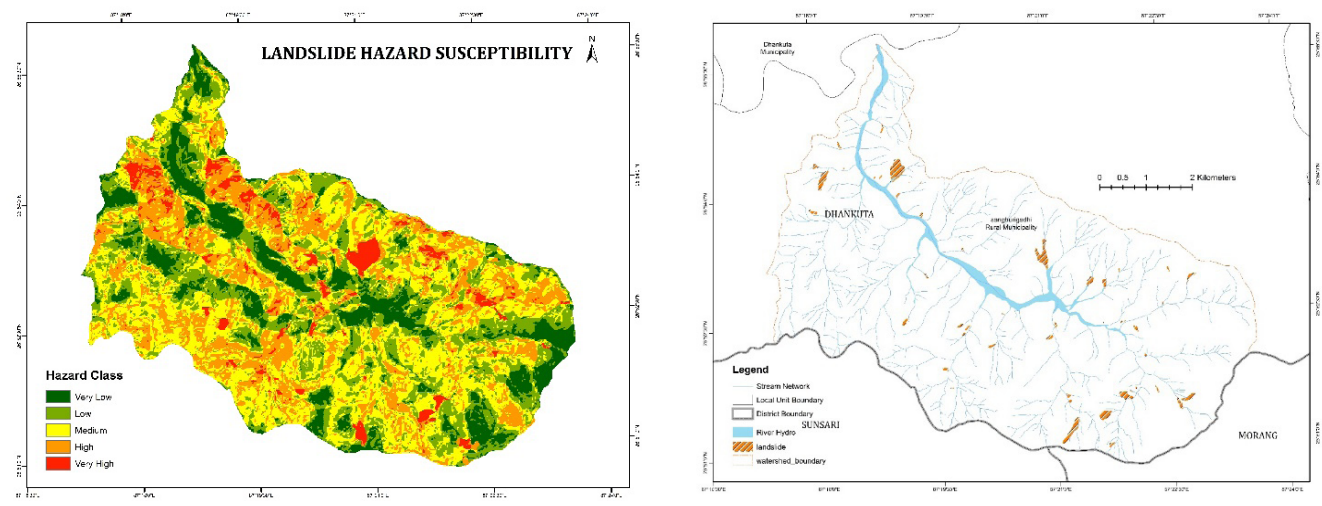

Figure 5: Landslide susceptibility hazard maps 
The calculated value (Table 3) indicates that there is good accuracy index found in the Leoutikhola watershed area. The numerical value ranges indicate that the sum total weight of each parameter is based on their natural logarithm. According to this logarithm, the sum of maximum value represent the higher hazard susceptibility and low susceptibility related to the lower or negative values (Fig. 5).

This paper identified higher hazardous area using bivariate statistical index method. The calculated index value is categorized into the different ranges or classes e.g. very low, low, moderate, high and very high in the watershed area. The result illustrates that the land use \& land cover and forest areas have considered as the dominant factors of landslide hazard. In the study area, most of the landslide are occurred in patches of cultivated land on steep slopes. On the other hand, forest cover area has directly affected the deforestation and degradation of forest cover land. It is observed that land use and land cover are more prevalent factors in the watershed area. The aspect of slope is also more important to determine landslide hazards in the study area because east, west and south facing slopes receive more sunlight (of Budimorang, Bhedetar) as compared to north facing slope. The humid and moist climatic condition of the upper catchment of watershed observed intense landslide hazard (Table 3).

Table 3: Spatial extension of landslide hazard susceptibility

\begin{tabular}{c|l|c|c|c|c|c}
\hline S.N. & $\begin{array}{c}\text { Hazard } \\
\text { Class }\end{array}$ & $\begin{array}{c}\text { Total Number } \\
\text { of Pixel in } \\
\text { whole map }\end{array}$ & $\begin{array}{c}\text { Hazard Area } \\
\text { in (Hectare) }\end{array}$ & $\begin{array}{c}\text { Hazard } \\
\text { Area in } \\
(\%)\end{array}$ & $\begin{array}{c}\text { Landslide Area } \\
\text { (Hectare) }\end{array}$ & $\begin{array}{c}\text { Area in } \\
\text { Percent }\end{array}$ \\
\hline 1 & Very Low & 30925 & 695.8 & 14.0 & 1.6 & 2.86 \\
2 & Low & 54280 & 1221.3 & 24.5 & 5.87 & 9.95 \\
3 & Moderate & 75161 & 1691.1 & 34.0 & 13.46 & 22.80 \\
4 & High & 51325 & 1154.8 & 23.2 & 13.41 & 22.72 \\
5 & Very High & 9665 & 217.5 & 4.4 & 24.59 & 41.67 \\
\hline
\end{tabular}

Source: Final landslide hazard map

The spatial coverage of landslide hazard class based on natural logarithm weighted value related to the spatial extension of landslide distribution. Result of hazard mapping has a positive correlation with landslide occurrences in this Leoutikhola watershed. The Hazard class high and very high holds the 27.6 percent area of the watershed and it includes 64.39 percent area of current landslide area. About 34 percent area of the watershed contains in moderately hazard class, which included 22.8 percent area of total landslide. The low classes and very low holds the 38.5 percent area of the watershed which represents 11 percent of total observed calculation. On the bivariate statistical 
index method, the hazard susceptibility classes should represent about 25 to 30 percent of the total area (Western, 1993). The principle-based recommendation accords with the result of hazard mapping of the watershed. The result indicates that 27.6 percent of the total area of this watershed comprised of high and very high hazard class.

\section{Conclusion}

The GIS based landslide hazard mapping using bivariate statistical index is the best and more applicable statistical method for landslide hazard mapping. It is an established fact that the slopes of the watershed, aspects, distances from hydro stream and land use and land cover have significant relation to occurrences of landslide hazard in the case of mid hill or lesser Himalaya in Nepal. These factors significantly contributing to landslides. The majority of landslide hazard occurred in the steep slope gradient of landscape. The east, south \& north aspects of the topography have a remarkable distribution of landslide hazard. Land resources e.g. cultivation fields and forests have been more vulnerable due to the direct exposure of landslide. The closet distances within 100 meters from the mainstream of stream have a good facts and evidences that have significant contribution to geomorphic processes in hill slope terrains. In this regard, an academic geographic course of university should make it mandatory in the curriculum. Similarly, GIS is appropriate tool for analyzing this so, GIS also has incorporated for the course of academia. On the other hands, students of geography also have an opportunity to learn practical knowledge through GIS. Landslide and other geomorphic processes are very complex concepts for the understanding of geography students. In this case this kind of tools and techniques will be fruitful for effective learning.

\section{References}

Ayala, I. A. (2002). Natural hazards, vulnerability and prevention of natural disasters in developing countries. Geomorphology, 47, pp. 107-124.

Dahal, R.K., Hasegawa, S., Nonomura, A., Yamanaka, M., Dhakal, S., \& Paudyal, P. (2008). Predictive modelling of rainfall-induced landslide hazard in the Lesser Himalaya of Nepal based on weight-of-evidence. Geomorphology, 102 (3-4), pp. 496-510.

Dhakal, A. S., Amada, T., \& Aniya, M. (2000). Landslide hazard mapping and its evaluation using GIS: An investigation on sampling schemes for a grid-cell based quantitative method. Photogrammetric Engineering \& Remote Sensing, 86, pp. 981-989.

Dhital, MR., Khanal, N., Thapa, K. B. (1993). The role of extreme weather events, mass movements, and land use changes in increasing natural hazards, a report 
Tika Ram Linkha, Dil Kumar Rai \& Furbe Lama / Landslide Hazard Mapping: GIS ...

of the preliminary field assessment and workshop on causes of recent damage incurred in south-central Nepal. Kathmandu: ICIMOD.

Devkota, K.C., Regmi, A. D., Pourghasemi, H. R., Yohida, K., Pradhan, B., Ryu, I.C., Dhital, M. J. \& Althuwaynee, O. F. (2012). Landslide susceptibility mapping using certainty factor, index of entrophy and logistic regression model in GIS at their comparison at Muglin - Narayangadh road section in Nepal Himalaya. Nat Hazards, 65, pp.135-165.

Central Bureau of Statistics (CBS) (2013) Environment statistics of Nepal. Kathmandu: National Planning Commission Secretariat. Government of Nepal.

Gardner, R. A. M., \& Gerrard, A. J. (2002). Relationships between land sliding and land use in the Likhu Drainage basin, Middle Hills of Nepal. Mountain Research and Development, 22, pp. 48-55.

Goudie, A. S. (1992). Geomorphological techniques. London: Allen \& Unwin.

Ghimire, M. (2011). Landslide occurrences and its relation with terrain factors in the Siwalik Hills, Nepal: case study of susceptibility assessment in three basins. Nat Hazards, 56, pp. 299-320.

Gupta, A. (2012). Tropical geomorphology. New Delhi: Cambridge University Press.

Heuberger, H., Masch. L., Preuss. E., \& Schrocker, A. (1984). Quaternary landslides and rock fusion in central Nepal and in the Tyrolean Alps. Mountain Research and Development, 4, pp. 345-362.

Ives, J. D., \& Messerli, B. (1981). Mountain hazards mapping in Nepal: introduction to an applied mountain research project. Mountain Research and development, 1, pp. 223-230.

Khanal, N. R., Shrestha, M., \& Ghimire, M. (2007). Preparing for flood disaster: Mapping and assessing hazard in the Ratu watershed, Nepal. Kathmandu: ICIMOD.

Khanal, N. R., Banskota, K., Shrestha,A. B., Mool, P., \& Achaya, C. P. (2013). Bhotekoshi/ Sun koshi river, Nepal: Potential GLOF risk assessment and management. In A.B. Shrestha, \& S.R. Bajracharya (Eds.), Case Studies on Flash Flood Risk Management in Himalayas. Kathmandu: ICIMOD/USAID, pp. 12-17.

Kienholz, H., Hafner, H., Schneider, G., \& Tamrakar, R. (1983). Mountain hazards mapping in Nepal's Middle Mountains, maps of land use and geomorphic damages (Kathmandu-Kakani area). Mountain Research and development, 3 (3), pp. 195-220. 
Laban, P. (1979). Landslide occurrences in Nepal. Kathmandu: His Majesty's Government (HMG Nepal/Food and Agriculture Organization (FAO) and United Nation Development Program (UNDP), Ministry of Forest, Department of Soil Conservation, Integrated Watershed Management.

LRMP (1984). Land capability mapping, scale 1: 25,000. Kathmandu: Kenting Earth Sciences Limited.

Pelty, D.N., Hearn, G. J., Andrew, H., Rosser, N. J., Dunning, S. A., Oven, K., \& Mitchel W., A. (2012). Trends landslide occurrences in Nepal. Nat Hazards, 43, pp. 2344.

Pradhan, A. M., Dawadi, A., \& Kim, Y. T. (2013). Use of different bivariate statistical landslide susceptibility methods: A case study of Kulekhani watershed Nepal. Journal of Nepal Geological Society, 44, pp. 1-12.

Paudyal, P., \& Dhital, M. R. (2005). Landslide hazard and risk zonation of Thankot Chalnakhel area. Journal of Nepal Geological Society, 31, pp. 43-50.

Pradhan, B. K. (2007). Disaster preparedness for natural hazards: Status in Nepal. Kathmandu: ICIMOD/ EU.

Singh, S. (2012). Geomorphology. Allahabad: Prayag Pustak Bhawan.

Singh, S. (1992). Geomorphology and Remote Sensing in Environmental Management. New Delhi: Scientific Publisher.

Selby, M. J. (1993). Hillslope materials and processes. Oxford University Press, Oxford.

Van Western C. J. (1997). Statistical landslide hazard analysis. ILWIS Application Guide, ITC Netherlands, pp. 73-84. 